Buchanan was married for fifty-four years to Lucy Perry Buchanan, who survives him. He is also survived by a sister, Phyllis Yeasel, of Lewistown, Ohio; a daughter, Lucia Buchanan Pierce, of Washington, D.C.; and a son, Christopher Franklin Buchanan, a daughter-in-law, Susan Nichols, and two grandchildren, Katie and Peter, all of Arlington, Virginia.

He was a member of the First Unitarian-Universalist Church, Columbus. A memorial service was held on Sunday, November 16, 2003. The family requests that, in lieu of other memorials, contributions be made in his name to Education About Asia, c/o Association for Asian Studies, 1021 East Huron Street, Ann Arbor, Michigan 48104.

LUCIEN ELLINGTON

University of Tennessee at Chattanooga

\title{
STEVEN GRAW
}

(August 3, 1946-September 21, 2003)

The Cornell University Department of Development Sociology mourns the loss of graduate student Steven Graw, who lost a courageous battle with cancer this year. Steve was distinguished by his profound ethical relationship to the world, which also informed his academic research. He played a pioneering role in the U.S.-Vietnamese reconciliation project and continued his inspiring involvement in a range of causes over the years that he spent in Ithaca (beginning in 1991). His master's thesis, "Nam Tien and the Development of Vietnamese Regionalism," broke new ground in weaving a historical account of southern Vietnamese regionalism with a contemporary political perspective on the Vietnam War. Steve's $\mathrm{PhD}$ research involved more than two years in the field, in Vietnam and the Philippines, where he examined the impact of remittances from migrant-family members on rice-farming cultures. His poster depicting this research won a graduate-student poster award at the Rural Sociological Society meetings in Albuquerque, New Mexico, in 2001. He will be missed, especially by his wife, Emily, and his daughters, Kwan-Yin and LeeAnn.

PhiLip MCMichael

Cornell University 